contacten met andere humanisten. De publicaties bestaan enerzijds uit poëzie, zoals de bundel Poemata Sacra, en anderzijds uit historische en filologische commentaren, waarvan die op Suetonius het bekendst zijn. Contacten had Torrentius met andere humanisten, zoals Schott, Lipsius en Lampsonius, en met de drukker Plantijn. Dit artikel wil als een aanzet worden beschouwd tot een veel gedetailleerder onderzoek naar Torrentius' werken en brieven.

In het volgende artikel van de bundel, 'Laevinus Torrentius als tweede bisschop van Antwerpen' (61-85), besteedt M. J. Marinus op gestructureerde wijze aandacht aan zijn ambtsperiode als bisschop van Antwerpen van 1587 tot zijn overlijden in 1595. Torrentius stond voor de zware opgave om de stad en het bisdom na de Spaanse verovering in kerkelijk opzicht opnieuw op te bouwen, waarbij conflicten met zijn eigen kapittel niet van de lucht waren. Voorts komen in dit artikel in het kort de politieke opvattingen en activiteiten van de bisschop als staatsman aan de orde.

In de twee laatste artikelen, 'Laevinus Torrentius, kunstliefhebber?', van J. van Damme (8699) en 'Portretten van Laevinus Torrentius. Historische, iconografische en inhoudelijke aspecten', van S. Grieten (101-105), wordt hij uit kunsthistorisch oogpunt bekeken. Volgens Van Damme was Torrentius geen kunstliefhebber, hetgeen hij mede aannemelijk maakt aan de hand van uittreksels uit de inventaris van het bisschoppelijk paleis, gemaakt direct na het overlijden van de bisschop (als bijlage bij dit artikel opgenomen). S. Grieten behandelt ten slotte, wellicht wat te beknopt, de portretten van Torrentius.

In de meeste artikelen wordt, in tegenstelling tot wat de titel van het boek aangeeft, vooral aandacht besteed aan Torrentius als humanist. De stukken zijn over het algemeen geschreven in een vlotte en leesbare stijl en zijn voorzien van een uitgebreid notenapparaat. Er is een groot aantal bronnen gebruikt, waarbij met name de correspondentie en publicaties van Torrentius vermeld dienen te worden.

Wat de presentatie betreft, moet rekening worden gehouden met het feit dat het boek in grote haast is ontstaan, waardoor nogal wat onnauwkeurigheden en typefouten zijn achtergebleven.

W. H. M. Fries

K. W. Swart, Willem van Oranje en de Nederlandse Opstand 1572-1584, M. E. H. N. Mout, H. F. K. van Nierop (Den Haag: Sdu uitgeverij Koninginnegracht, 1994, 311 blz., f59,90, ISBN 901208135 1).

Op het schrijven van een biografie van de 'Vader des Vaderlands' Willem van Oranje heeft in deze eeuw weinig zegen gerust. Na de grote bronnenpublicaties van de negentiende eeuw en de belangwekkende RGP-uitgave Resolutiën der Staten-Generaal waren de grondstoffen rijkelijk voorhanden. Felix Rachfahl stelde zich ten doel de biografie van Oranje te schetsen aan de hand van een beschrijving van de Nederlandse Opstand, maar vertilde zich aan deze ambitieuze opzet; hij bereikte slechts het jaar 1569 zodat zijn magistrale werk een torso bleef. Een tweede maal vond dit plaats met de biografie door K. W. Swart. Deze vatte reeds lang voor de herdenking van 1984 het plan op om een biografie over Willem van Oranje te schrijven. Na de hausse van geschriften in en rondom het herdenkingsjaar 1933 was weinig van importantie verschenen en er bestond ook behoefte aan een nieuwe, minder door de traditionele verering gedomineerde visie.

Het werk kwam niet in 1984 gereed en na het onverwachte overlijden van Swart in 1992 bleek dat alleen de periode 1572-1584 gereed was gekomen. Dit deel bleek evenwel dermate waardevol van inhoud te zijn dat de familie naar mogelijkheden heeft gezocht om toch tot uitgave te 
komen. Alastair Duke schreef een aanloop naar het jaar 1572 en Raymond Fagel controleerde de annotatie aan de hand van de oorspronkelijke aantekeningen van Swart. Op deze wijze is een drukperswaardig product verkregen. Zoals het werk van Rachfahl, is het een torso en zal om die reden waarschijnlijk nimmer in een buitenlandse editie verschijnen of een herdruk beleven. Swart is weinig mededeelzaam geweest over zijn project en de criteria die hij daaraan ten grondslag legde. Het manuscript bevatte geen verantwoording van zijn methodiek. We zijn op het werk zelf aangewezen om zijn opvattingen te achterhalen. Een eerste opvallend kenmerk is het buiten beschouwing laten van de recente historiografie. De naam van een kenner van de Opstand als J. J. Woltjer zoekt men tevergeefs in de literatuuropgave. Swart wenste vooral uit de bronnen te schrijven, naar Rankes ideaal: Wie es eigentlich gewesen war. Zijn werk is een poging tot 'objectieve' geschiedschrijving, ontdaan van de vooringenomenheid van de verschillende richtingen die voorheen het beeld kleurden.

Men kan zich afvragen of een dergelijke handboekmatige aanpak voor een biografie de meest gewenste is. Het uit de bronnen schrijven heeft grote voordelen: allerlei in de historiografie ingeslopen onjuistheden worden geëlimineerd, overdreven heldendom wordt tot concrete feiten teruggebracht. Maar het overwegend hanteren van feiten uit de eigentijdse bronnen heeft het gevaar dat voorbij wordt gegaan aan analyses gebaseerd op meeromvattend onderzoek, zoals de ontwikkeling van de politieke instellingen, de aanhang van de nieuwe religie in de verschillende gebieden, de sociale verhoudingen in de samenleving en de economische belangen van steden en gewesten. In een histoire événementielle, om het ietwat overdreven uit te drukken, komt men slechts terloops tot constateringen op deze terreinen van onderzoek.

Zo constateert Swart dat de prins na 1579 veel minder gelukkig was in zijn streven. Hij signaleert daarbij niet dat de samenwerking met de provincies Holland en Zeeland in het verlengde lag van zijn vroegere functie als stadhouder en dat de prins bij het opereren met het logge lichaam van de Staten-Generaal van de verenigde provinciën niet in de plaats kon treden van het vroegere koninklijke bestuursapparaat dat bovendien slechts met de Staten als geldgevers te maken had. Swart noemt de muiterij van de Spaanse soldaten in 1576 als aanleiding voor de totstandkoming van de Pacificatie van Gent terwijl voor deze uitbreiding van de Opstand tot alle gewesten vooral ook de belemmeringen van de handel als gevolg van het beheersen van de rivieren door Holland en Zeeland bijdroegen. Andere grote lijnen blijven onderbelicht zoals het uitgebreide netwerk van vorsten en diplomaten waarover de prins na het begin van de Opstand bleek te kunnen beschikken. Een voorafgaande studie over de jaren 1551-1572 was hiertoe verhelderend geweest. Van een ontmythologisering van Willem van Oranje, zoals sommige krantenkoppen boven de aankondiging van het boek suggereerden, is bij Swart geen sprake. Terecht haalt hij de prins weg uit het kamp van de strenge calvinisten, maar overigens prijst hij hem keer op keer wegens zijn weloverwogen keuzen op diverse moeilijke momenten zoals in de kwestie van samenwerking met Anjou na 1583. Hij geeft Oranje wat hem toekomt zonder te vervallen in overdreven verering of denigreren.

Daarbij komen telkens tot dusverre onbekende details naar voren die Swart met name heeft ontleend aan twee voordien onbekende bronnen: twee 'formulaerboecken' uit de jaren 15721575 met commissies en brieven die voor vroegere biografen verscholen lagen in de collectie Van Bevemingh-Van der Dussen in het Koninklijk Huisarchief en eerst bij een herinventarisatie van het archief van Willem van Oranje omstreeks 1940 aan dat archief zijn toegevoegd. Daarnaast heeft Swart zijn gegevens ook verrijkt met vondsten in stedelijke archieven in Nederland. Swart heeft zijn gegevens in een compositorisch heldere betoogtrant gebracht, soms, om verschillende ontwikkelingen te scheiden, ietwat overlappend, maar nooit zodanig dat de lezer het spoor bijster raakt. Zijn biografie is dan ook een goed leesbaar boek, ook voor een breder publiek. Wij beschikken in de biografieën van Rachfahl en Swart thans over twee vrijwel op 
elkaar aansluitende torso's die zeer uiteenlopend van opzet zijn. Daarbij heeft Rachfahl teveel vanuit het algemene gebeuren geschreven en heeft Swart te weinig grote lijnen erbij betrokken. De ideale biografie zou daartussenin moeten staan. De door P. J. Blok uitgesproken wens dat een goede biografie over de Vader des Vaderlands moet worden geschreven blijft in dit opzicht actueel. Maar wie zich ertoe geroepen voelt, zij erop verdacht dat het beschrijven van 's prinsen levenswerk ook een levenswerk dient te zijn, wil het niet in een derde torso resulteren.

Een goede recensie dient ook enige vitterijen te bevatten. Het boek is vol van kleine foutjes die hadden kunnen worden vermeden. Zo lezen we op 112 instignatie, op 154 bedeloorden, op 160 heften op, op 190 welsprakenheid, op 220 vogelingen, om enige zetfouten te signaleren. Op 206 spreekt Swart van een landraad ten oosten en ten westen van de Maas. Die termen zijn niet correct: de Landraad was te Brussel gevestigd en competent voor het gebied beneden de Maas; wegens de lange verbindingslijnen werd een Landraad Beoostenmaze ingesteld voor het gebied boven de Maas. De opmerking op 238 dat Louise de Coligny de Nederlandse geschiedenis heeft beïnvloed doordat zij het leven schonk aan een zoon Frederik Hendrik, vind ik oubollige oudemannenpraat.

\section{J. H. Kluiver}

B. J. Kaplan, Calvinists and libertines. Confession and community in Utrecht 1578-1620 (Oxford: Clarendon press, 1995, xv + 347 biz., £40,-, ISBN 019820283 0).

In de kerkgeschiedenis van de Nederlanden neemt Utrecht een geheel eigen plaats in, vóór de hervorming als centrum van het enige bisdom in de Noordelijke Nederlanden, en na 1578 omdat het de enige stad was waar enkele jaren twee protestantse kerken een erkende plaats hadden. Het conflict tussen calvinisten en libertijnen kreeg daardoor een bijzonder karakter. Aan dit conflict heeft Benjamin Kaplan een voortreffelijk boek gewijd.

In een proloog schetst hij de ontwikkelingen in Utrecht tot 1578. In juli van dat jaar beriep een groep calvinisten Werner Helmichius, een Utrechts burger die in Genève en Heidelberg had gestudeerd, tot de eerste predikant van een orthodox-calvinistische gemeente. In juni van dat jaar had een van de twee pastoors van de Jacobskerk, Hubert Duifhuis, openlijk met de roomse kerk gebroken. Hij had de stad moeten verlaten, maar met steun van de magistraat keerde hij al in augustus weer terug in zijn oude parochie en preekte in een protestantse, maar verre van calvinistische geest, voor een groot gehoor, maar tot verdriet van Helmichius en de zijnen.

Daarna tekent de schrijver in de eerste twee hoofdstukken met zorg de mentaliteiten en opvattingen van beide partijen, de calvinisten en de libertijnen. De calvinisten wensten een strenge kerkelijke tucht, de libertijnen wezen deze af. Kaplan karakteriseert de laatsten vooral aan de hand van de preken van Duifhuis. Hij legt de nadruk op hun spiritualisme, sterk beïnvloed door de laatmiddeleeuwse mystiek. Met de erudiete Erasmus hadden zij weinig te maken. Natuurlijk waren niet alle libertijnen van Duifhuis' geest doortrokken, bij velen speelde ook een protestantse vorm van anticléricalisme een rol.

In het derde hoofdstuk beschrijft hij de voor Nederland unieke sociale structuur van Utrecht: grote kooplieden ontbraken en de stad was verdeeld tussen ambachtslieden en een door de adel gedomineerd patriciaat, waarbij de rijke kapittels een versterking van het laatste betekenden. Een proto-proletariaat ontbrak. De politieke macht van de gilden was in 1528 gebroken, maar de schutterijen speelden onder andere in 1576-1577 bij het beleg van Vredenburg een grote rol 